Int. J. Morphol.,

28(3):697-701, 2010

\title{
Follicular-Stromal Interaction in Mare Ovary During the Reproductive Cycle
}

\author{
Interacción Estroma-Folículo en el Ovario de la Yegua Durante el Ciclo Reproductivo
}

${ }^{*}$ Carolina Smok S. \& ${ }^{* *}$ Mariana Rojas R.

SMOK, S. C. \& ROJAS, R. M. Follicular-stromal interaction in mare ovary during the reproductive cycle. Int. J. Morphol., 28(3):697$701,2010$.

SUMMARY: Ovogenesis and foliculogenesis in the mare differ from other farm animals and therefore, gamete manipulation, in vitro fertilization and embryo transfer have been very difficult. The histologic traits of ovaries from 12 mares, in estrus and diestrus were studied. Number and size of follicules and corpora lutea were recorded. The ovarian stroma was evaluated using the pricosirius technique for collagen. A simple morphometric analysis was done using computerized scanner programs. During late estrus, one dominant follicle $(46 \pm 4 \mathrm{~mm})$ is seen. The surrounding stroma contains collagen I and III. By the end of the estrus, one hemorrhagic follicle is seen, plus one or two small follicle ( $2 \mathrm{~mm}$ in size). In early diestrus there is a corpus luteum $(43-60 \mathrm{~mm})$ and some antral follicles (6 \pm 1$)$. Collagen I forms strands inside the corpus luteum and predominates in the perifollicular ovarian stroma. Modifications of the extracellular matrix may change cell function by way of integrines, the matrix being in turn modified by hormones and other tissular factors. Estrogens can be related to collagen III predominance in ovarian stroma whereas progesterone is associated with increased collagen I. Therefore, follicular-stromal interactions are important in ovarian histophysiology.

KEY WORDS: Follicle; Stroma; Mare ovary; Seasonality.

\section{INTRODUCTION}

Mare ovary has been described macroscopically since long years ago by direct imaging using ultrasound for veterinary diagnosis by Pierson \& Ginther (1987) and Ginther (1988). Coutinho da Silva et al. (2002) reported that in vitro matured equine oocytes can develop efficiently into viable embryos.

The mare is a seasonal breeder, being cyclic from spring to fall and remaining in anestrus in winter. This period is followed by a transitional phase until regular cyclic activity begins (Watson \& Al-zi' abi, 2002). The estral cycle lasts 20 to 23 days; the estral phase takes 6 days, and diestrus lasts 15 days. Ovulation occurs in the last or penultimate day of the estrus (Arthur et al., 1991).

Because of the differences between the equine ovary and other species of veterinary interest (Habel, 1988), in vitro handling of mare oocytes using methods that have been successful in other species are not useful in the equine and therefore, a new appraisal of mare ovarian physiology in terms of the peculiar microenvironment that interacts with differentiation of the oocyte is needed.

The aim of this study is to analyze the relationship between kinetic of the follicles and corpus luteum and their microenvironment, in terms of the extracellular matrix and connective tissue that surround those structures in the mare ovary. Our emphasis will be in components of the extracellular matrix (E.M.) which are known to regulate specific cell events in a fashion akin to the mode of action of growth factors, cytokins and hormones (Von der Mark et al., 1992).

The E.M. is mainly formed by different types of collagen and elastin (fibrilar E.M.) together with glycoproteins, glycosamins and proteoglycans (amorphous

\footnotetext{
* Programa de Magíster en Cs Biológicas, Mención Morfología, Facultad de Medicina, Universidad de Chile.

** Laboratorio de Embriología Comparada, Programa de Anatomía y Biología del Desarrollo, Facultad de Medicina, Universidad de Chile.

This work was partially supported by Project FONDECYT 1930-777
} 
E.M.) (Labat-Roberts et al., 1990). Among the collagen forms, type I is the most abundant and is found practically in all connective tissues. Type III is present in the first developmental stages of different connective tissues and persists in the adult in the reticular nets described in uterus, blood vessels and the skin. Among the non collagen glycoproteins of the E.M. the most relevant is laminin, which is found in the basement membranes and seems to play a crucial role in its architecture, besides cell adhesion, growth, migration, and differentiation (Colognato \& Yurchenco, 2000).

These are some of the stromal components forming the microenvironment of the follicles that may control changes occurring in the oocytes. In this work, mare ovaries were analyzed in terms of follicular developmental traits, number and diameter of growing and atretisic follicles, corpora lutea diameter, and in the E.M., the presence of collagen I and distribution of collagen III was determined.

\section{MATERIAL AND METHOD}

Ovaries from 12 sexually active mares were used. The animals were clinically healthy, devoid of any reproductive pathology and in good nutritional status. Tissues were obtained at the abattoir and quickly brought in an ice-box to the laboratory.

Each ovary was measured (length and width) and its volume was estimated by water displacement. The method described by Arthur et al. to determine the stages of the cycle of the animals was used. Right and left ovaries of 8 animals were processed for microscopic analysis, follicular fluid being first obtained for biochemical and steroidal assays. Left ovaries of another 4 mares were fixed in alcoholic Bouin and processed for histochemical identification of collagen with the tricomic picrosirius technique (Junqueira et al., 1982). Other sections were stained with H.E. or Alcian Blue.

The picrosirius technique allows identification of collagen types under polarized light, since collagen I shows birefringence, with colours from yellow to red, whereas collagen III appears green.

The number of growing follicles and corpora lutea was recorded. Morphometric methods used for ultrasonographic observations by Pierson \& Ginther were adapted for our microscopical analyses, in order to make comparisons between both types of data. The macroscopic characteristics of the follicular fluid were also noted.
Statistical analysis includes means, standard deviation of the means, and coefficient of variation. Some parameters were quantified using an interactive system with a manual Logitech scanner and image digitizing in a computerized system with a morphometric program deviced by Bozzo \& Retamal (1991). Qualitative variables like the inmunhistochemical or picrosirius results were expressed as: (-) no staining; (+) scarce; (++) large quantity.

\section{RESULTS}

The main characteristics of follicular development in the different periods of the ovarian cycle are summarized in Table I.

In the ovaries of the mares at the beginning of the estrus, the number of antral follicles was over 10. The larger diameter was $20 \mathrm{~mm}$ but the difference between them did not exceed $5 \mathrm{~mm}$ (Fig. 1). In late estrus, larger follicles were found. Their mean diameter $(46 \pm 4 \mathrm{~mm})$ exceeds by more than $30 \mathrm{~mm}$ the size of the intermediate follicles $(X=16.5 \pm$ $2 \mathrm{~mm}$ ).

The smaller antral follicles (up to $25 \mathrm{~mm}$ ) contain a jelly-like fluid. The external granulose layer is made up by 6 to 7 layers of follicular cells $(X=40 \pm 7 \mathrm{~mm})$. The larger antral follicles $(>30 \mathrm{~mm}$ ) have an aqueous follicular fluid. Their external granulose layer is thin $(24 \pm 2 \mathrm{~mm})$.

The follicular theca is difficult to identify from the rest of the stroma. With the picrosirius technique, the inner theca is not stained and the neighboring stroma contains collagen III (Fig. 2). The stroma away from the antral follicles, however, is rich in collagen I.

In the ovulatory period, the hemorrhagic follicle reaches $40 \mathrm{~mm}$ in diameter, thus occupying $83 \%$ of the ovarian volume. In early diestrus, the corpus luteum measures from 43 to $60 \mathrm{~mm}$ and occupies practically the whole ovarian volume, without protruding out of the organ (Fig. 3). The number of antral follicles increases to $6 \pm 1$ and their diameters range from 11 to $14 \mathrm{~mm}$.

By late diestrus the ovaries decrease in size ( $43 \pm 7$ $\mathrm{mm})$. The corpus luteum reduces it volume and the antral follicles are $11 \pm 4$ in diameters. The largest follicles (usually not more than 2), reach 20 to $27.5 \mathrm{~mm}$. In this stage a wave of follicular atresia may be found. In follicles of different sizes, the outer granulose layer is invaded by capillaries. Pycnotic nuclei and atretic bodies are found in the follicular fluid. 
In the ovarian stroma, dense connective tissue is found and collagen I predominates. The fibers show a more sparce distribution close to the follicles. Collagen I is also found encircling the corpus luteum (Fig. 4). Thin strands of collagen penetrate this gland, making up some septa. Collagen III is practically not recognizable.

Table I. Ovarian diameter and number and diameter of antral follicles according stage of the cycle.

\begin{tabular}{lccc}
\hline Stage of the cycle & Ovarian diameter & Number of antral follicles & Diameter of the largest follicle \\
\hline Early estrus & $51.2 \pm 8$ & $12 \pm 2$ & $20.0 \pm 2$ \\
Late estrus & $65.0 \pm 10$ & $2 \pm 1$ & $46.0 \pm 4$ \\
Early diestrus & $45.0 \pm 25$ & $6 \pm 1$ & $12.5 \pm 2$ \\
Late diestrus & $40.0 \pm 10$ & $11 \pm 4$ & $23.7 \pm 3.7$ \\
\hline
\end{tabular}

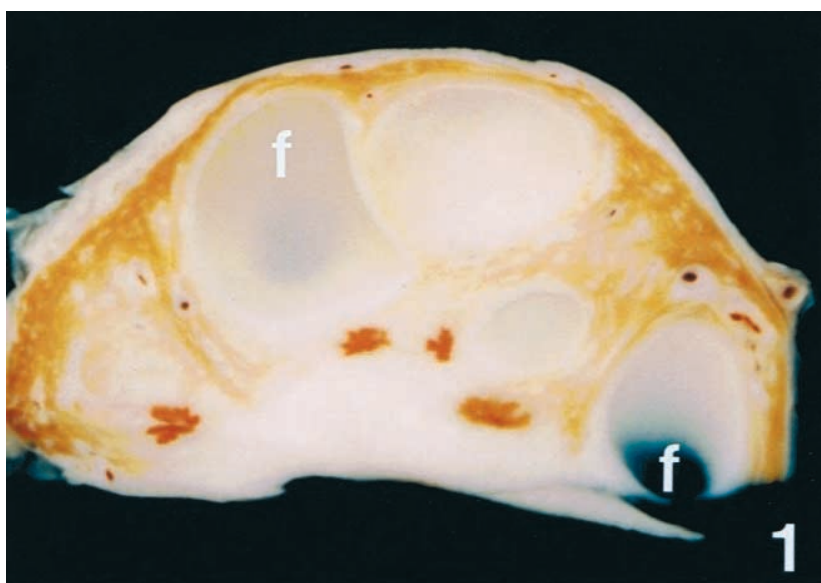

Fig.1. Section of early estrus ovary. Several follicles (f) can be identified (actual size).

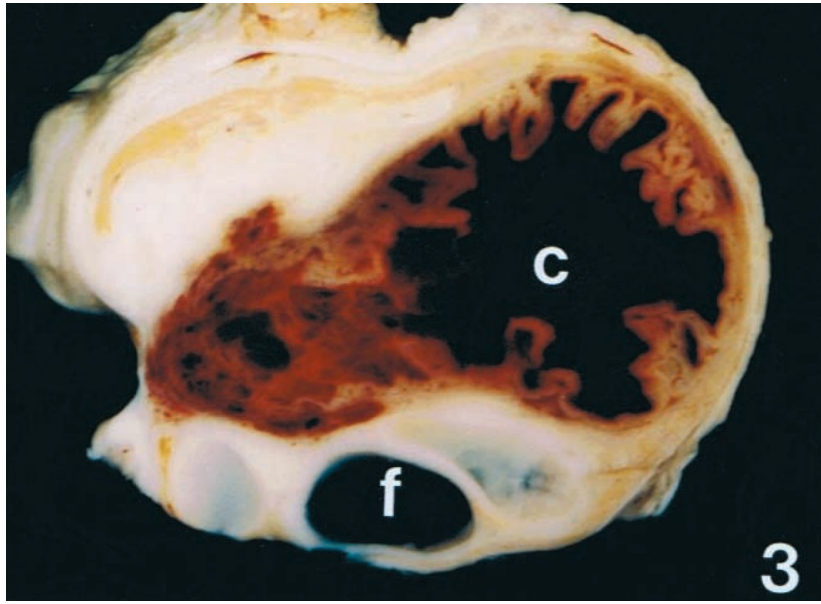

Fig.3. Section of one early diestrus ovary. One corpus luteum (c) and one follicle (f) are seen (actual size).

\section{DISCUSSION}

According to our results, the kinetics of follicles and corpora lutea is related to changes in the surrounding of the ovarian stroma, thus suggesting continuous interactions

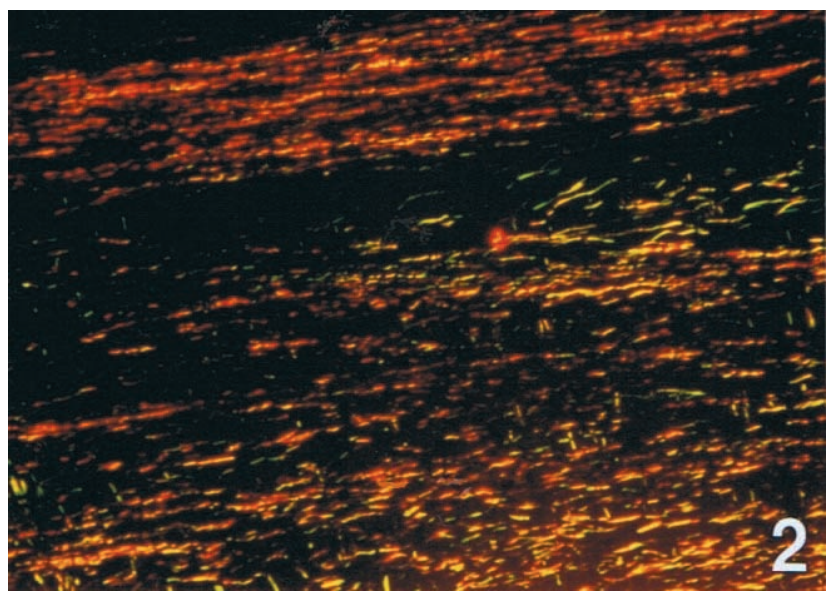

Fig.2. Section of the estrus ovary. Collagen $I$ is found in the perifollicular stroma (red fibers) as well as collagen III (green fibers). Picrosirius technique and polarized light 100X.

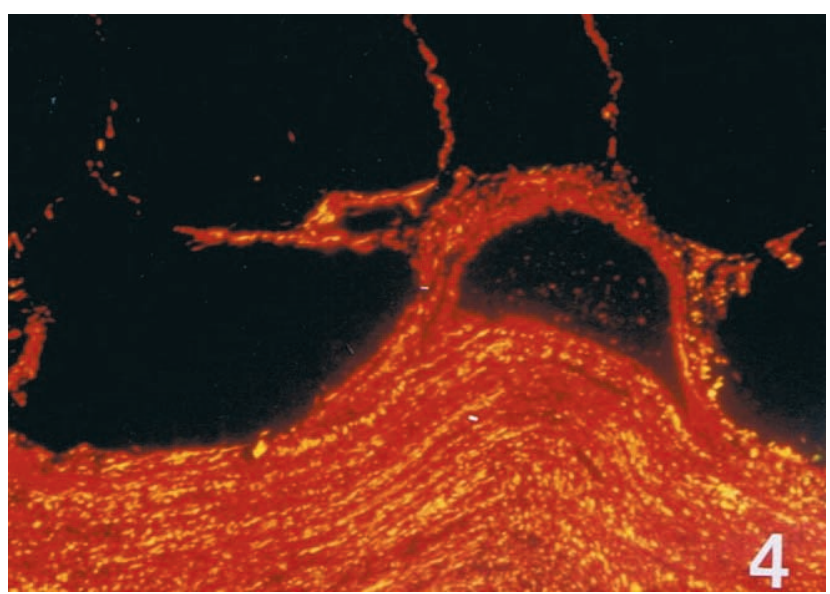

Fig.4. Diestrus. The corpus luteum (black structure) is seen surrounded by collagen I, that forms thin walls penetrating the gland. Picrosirius technique and polarized light 40X.

between parenchyma and stroma. Similar results were reported by von der Mark et al., indicating that E.M. components regulate different cellular events. 
The early diestrus is characterized by the presence of only one corpus luteum and a group of 3 to 4 follicles of 2 to $5 \mathrm{~mm}$ in diameter, which increase their size towards late diestrus. In this period the encircling stroma is formed by dense connective tissue, collagen I being predominant. This collagen type increases with the increase in progesterone levels (Hughes et al., 1972).

By late diestrus, an average of 11 to 12 antral follicles, of rather homogeneous diameter, are found in the ovary. The high estrogens levels found in this phase may induce oxytocin release by the corpus luteum. Oxytocin stimulates the production of prostaglandins by the uterus (McCracken et al., 1999), and they, in turn, produce ovarian luteolysis by 14 to 17 days after ovulation, with the subsequent fall in progesterone levels. These estrogens would also trigger LH release and maturation of LH receptors in the follicular theca (Adams \& Bosu, 1988).

Ovarian histology by early estrus resembles the late diestrus. Around 10 follicles can be identified with the naked eyes, with gradual differences in diameter. Thereafter sizes are different and by late estrus one follicle grows to be a $40 \%$ larger than the other follicles. These results are in agreement with the findings of Pierson \& Ginther and Ginther, in spite of the different techniques used in their studies.

Ovulation occurs before the end of estrus, $\mathrm{LH}$ levels being important for this event. According to Arthur et al., the mode of LH secretion is typical for the mare; it increases gradually and stays for prolonged time at a high level (for 5 to 6 days) before and after ovulation, thus being different pattern during the periovulatory period in other species.

During the period of follicular growth, together with high estrogens and LH levels, the ovarian stroma shows an important increase in collagen III. Collagen I decreases in the periphery of the larger follicles. It may be said that collagen III increase is related to rising estrogen levels that reach a peak near ovulation of 150 pg/ml (Adams \& Bosu; Arthur et al.).

In the present study, the connective tissue E.M. is a dynamic component that undergoes noticeable changes in relation to endocrine changes. In the progestational phase, there is an increase in collagen I synthesis. Against, in the estrogenic phase there is a predominance of collagen III fibers around the larger follicles. Tsafriri \& Reich (1999) postulated that in this period there is an increase in plasminogen activator induced by mural granulosa cells, to promote E.M. degradation.

The matrix establishes some sort of communications with the cells through their membrane receptors (integrins) and acts as a mediator for signals originated in the matrix. Thus, matrix modifications may alter cell functioning (Labat-Robert et al.), and hormones (or other factors) made by the follicular cells or the corpus luteum modify the ovarian stroma. A detailed accounting of these reciprocal interactions my give a better insight into ovarian histophysiolgy.

SMOK, S. C. \& ROJAS, R. M. Interacción estroma-folículo en el ovario de la yegua durante el ciclo reproductivo. Int. J. Morphol., 28(3):697-701, 2010.

RESUMEN: La ovogénesis y foliculogénesis en la yegua, difiere de otros animales de granja, y por lo tanto, la manipulación de gametos, fertilización in vitro y transferencia de embriones ha sido muy dificultoso. Se estudiaron las características histológicas de ovarios de 12 yeguas durante el estro y el diestro. Se registró el número y tamaño de los folículos y cuerpos lúteos. Se evaluó el estroma ovárico usando la técnica picrosirius para colágeno. Se realizó un análisis morfométrico simple utilizando un programa escáner computarizado. Durante el estro tardío, se observó un folículo dominante (46 $\pm 4 \mathrm{~mm})$. El estroma circundante contiene colágeno I y III. Para el final de este período, se aprecia un folículo hemorrágico, más uno o dos pequeños folículos ( $2 \mathrm{~mm}$ de tamaño). En diestro temprano, hay un cuerpo lúteo (43 - $60 \mathrm{~mm}$ ) y algunos folículos antrales (6 \pm 1 ). El colágeno I forma filamentos dentro del cuerpo lúteo y predomina en el estroma ovárico perifolicular. Modificaciones en la matriz extracelular pueden cambiar la función celular vía integrinas, la matriz está a su vez modificada por las hormonas y otros factores tisulares. Los estrógenos se pueden asociar a la predominancia de colágeno III en el estroma ovárico, mientras que la progesterona se asocia con un aumento de colágeno I. Por lo tanto, las interacciones estroma-folículo son importantes en la histofisiología del ovario.

PALABRAS CLAVE: Folículo; Estroma; Ovario de yegua; Estacionalidad. 


\section{REFERENCES}

Adams, G. \& Bosu, T. K. Reproductive physiology of the nonpregnant mare. An overview and update. Vet. Clin. North. Am. Equine Pract., 4(2):161-73, 1988.

Arthur, G. H.; Noakes, D. E. \& Pearson, H. Reproducción y Obstetricia en Veterinaria. $6^{\text {ta }}$ Ed. Interamericana. Mc Graw-Hill, 1991. pp.3-49.

Bozzo, S. \& Retamal, C. Gel-perfect: Geles unidimensionales, un nuevo método densitométrico para computadores personales. Arch. Biol. Med. Exp., 24:181-4, 1991.

Colognato, H. \& Yurchenco, P. D. Form and function: the laminin family of heterotrimers. Dev. Dyn., 218(2):213-34, 2000.

Coutinho da Silva, M. A.; Carnevale, E. M.; Maclellan, L. J.; Seidel G. E. Jr., \& Squires, E. L. Effect of time of oocyte collection and site of insemination on oocyte transfer in mares. J. Anim. Sci., 80(5):1275-9, 2002.

Ginther, O. J. Ultrasonic imaging of equine ovarian follicles and corpora lutea. Vet. Clin. North Am. Equine Pract., 4(2):197-213, 1988.

Habel, R. Ovario y útero. In: Anatomía Veterinaria Aplicada. 2nd Ed. Zaragoza, Acribia, 1988. pp.277-80.

Hughes, J. P.; Stabenfeldt, G. H. \& Evans, J. W. Estrous cycle and ovulation in the mare. J.A.V.M.A. 161:1367$74,1972$.

Junqueira, L. C.; Montes, G. S. \& Sánchez, E. M. The influence of tissue section thickness on the study of collagen by the Picrosirius-polarization method. Histochemistry, 74(1):153-6, 1982.

Labat-Robert, J.; Bihari-Varga, M. \& Robert, L. Extracellular matrix. FEBS Lett., 268(2):368-93, 1990.

McCracken, J. A.; Custer, E. E. \& Lamsa, J. C. Luteolysis: a neuroendocrine-mediated event. Physiol. Rev., 79(2):263-323, 1999.

Pierson, R. A. \& Ginther, O. J. Follicular population dynamics during the estrous cycle of the mare. Anim. Reprod. Sci., 14(3):219-31, 1987.
Tsafriri, A. \& Reich, R. Molecular aspects of mammalian ovulation. Exp. Clin. Endocrinol. Diabetes, 107(1):1$11,1999$.

Von der Mark, K.; von der Mark, H. \& Goodman, S. Cellular responses to extracellular matrix. Kidney Int., 41:632-40, 1992.

Watson, E. D. \& Al-zi'abi, M. O. Characterization of morphology and angiogenesis in follicles of mares during spring transition and the breeding season. Reproduction, 124:227-34, 2002.

Correspondence to:

Dra. Mariana Rojas R.

Laboratorio de Embriología Comparada.

Programa de Anatomía y Biología del Desarrollo

Fac. de Medicina, ICBM

Universidad de Chile

CHILE

Email: dramrojas@hotmail.com

Received: 28-04-2010

Accepted: 12-06-2010 
